\title{
Pemberton's sign in SVC syndrome from metastatic renal cell carcinoma
}

\author{
Neil Keshvani, Christina Yek, David H Johnson
}

Department of Internal

Medicine, University of Texas Southwestern, Dallas, Texas, USA

\section{Correspondence to Dr Neil Keshvani, neil.keshvani@gmail.com}

Accepted 10 March 2018

\section{DESCRIPTION}

A 52-year-old man with no medical history presented to the emergency department after a syncopal episode. The patient reported reaching over his head to lift an object at work when he felt transiently light-headed, lost consciousness and fell to the floor. He denied any preceding palpitations or chest pain. He reported intermittent light-headedness and nausea for the past week, facial and neck swelling for several weeks, and an unintentional 20-pound weight loss over the past 3 months.

On physical exam, his temperature was $37.0^{\circ} \mathrm{C}$, heart rate was $105 / \mathrm{min}$, respiratory rate was 14 / min and blood pressure was $137 / 84 \mathrm{~mm} \mathrm{Hg}$. $\mathrm{He}$ had mild neck and facial erythema and oedema, which became significantly more pronounced on elevation of the arms over the head (figure 1). A CT angiogram of the chest (figure 2 ) revealed a $6.9 \times 4.7 \times 5.8 \mathrm{~cm}$ mass in the mediastinum causing mass effect on the anterior aspect of the right main pulmonary artery and occluding the superior vena cava (SVC). The CT chest also revealed a partially imaged soft tissue mass arising from the upper pole of the right kidney, and dedicated CT abdomen and pelvis revealed a large $10.8 \mathrm{~cm}$ right renal mass. A biopsy of the chest mass subsequently demonstrated pathology suggestive of renal cell carcinoma. The patient was diagnosed with metastatic renal cell carcinoma causing SVC syndrome.

SVC syndrome is the obstruction of blood flow through the SVC. In the past, infectious aetiologies including syphilis and tuberculosis were a prevalent cause of SVC syndrome. ${ }^{1}$ However, malignancy now far exceeds infection as the most common cause of SVC syndrome; of causative malignancies, primary lung cancer is the most likely, followed by lymphoma. Other non-malignant causes include thrombus secondary to

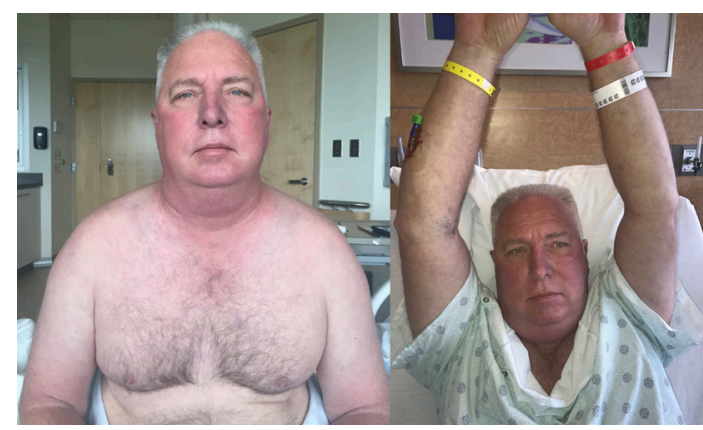

Figure 1 Pemberton's sign with elevation of the bilateral arms.

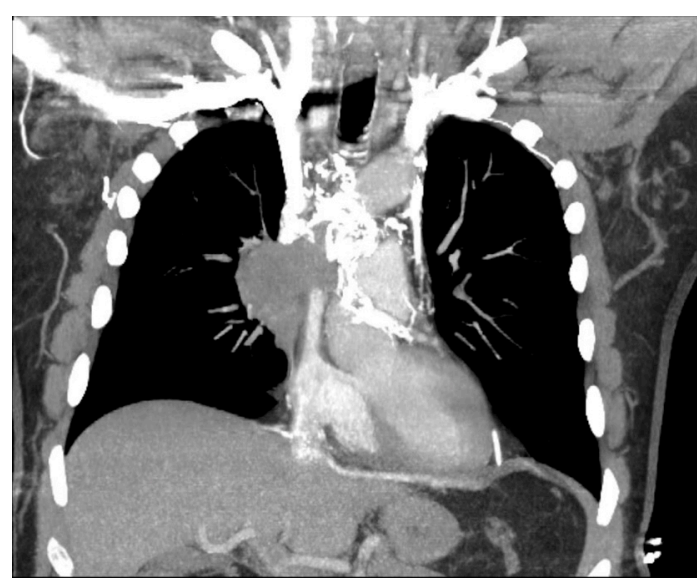

Figure 2 CT angiogram of the chest revealing a mediastinal mass causing compression of the superior vena cava.

\section{Learning points}

- Pemberton's sign involves bilateral arm elevation, and a positive sign results in facial engorgement. The exam manoeuvre is useful for detecting superior vena cava (SVC) obstruction.

- Renal cell carcinoma is a rare cause of SVC syndrome from tumour metastasis compression of the vein.

vascular catheterisation, goitre or mediastinal fibrosis. ${ }^{1}$ The patient suffered from metastatic renal cell carcinoma, which is a rare and atypical cause of SVC syndrome.

Diagnosis of SVC syndrome is based primarily on imaging, but physical exam can help identify venous obstruction. Pemberton's sign (figure 1) was first reported by Dr Hugh Pemberton in 1946 and is characterised by facial plethora and venous engorgement following bilateral arm elevation. ${ }^{2}$ This phenomenon is attributed to clavicular movement causing a 'nutcracker' effect that compresses major venous structures and was traditionally associated with large substernal goitres. ${ }^{3}$ This physical exam finding is a quick manoeuvre that can be beneficial in diagnosing SVC syndrome from all aetiologies.

Contributors $\mathrm{NK}, \mathrm{CY}$ and $\mathrm{DHJ}$ made substantial contributions to conception or design of the work, or the acquisition, analysis or interpretation of data for the work; drafting of the work or revising it critically for important intellectual content; gave final approval of the version to be published; and agree to be accountable for all aspects of the work in ensuring that questions related to the 
accuracy or integrity of any part of the work are appropriately investigated and resolved.

Funding The authors have not declared a specific grant for this research from any funding agency in the public, commercial or not-for-profit sectors.

Competing interests None declared.

Patient consent Obtained.

Provenance and peer review Not commissioned; externally peer reviewed. (c) BMJ Publishing Group Ltd (unless otherwise stated in the text of the article) 2018. All rights reserved. No commercial use is permitted unless otherwise expressly granted.

\section{REFERENCES}

1 Wilson LD, Detterbeck FC, Yahalom J. Superior Vena Cava Syndrome with Malignant Causes. N Engl J Med Overseas Ed 2007;356:1862-9.

2 Pemberton HS. SIGN OF SUBMERGED GOITRE. The Lancet 1946:248:509.

3 De Filippis EA, Sabet A, Sun MR, et al. Pemberton's sign: explained nearly 70 years later. J Clin Endocrinol Metab 2014:99:1949-54.

Copyright 2018 BMJ Publishing Group. All rights reserved. For permission to reuse any of this content visit

http://group.bmj.com/group/rights-licensing/permissions.

BMJ Case Report Fellows may re-use this article for personal use and teaching without any further permission.

Become a Fellow of BMJ Case Reports today and you can:

- Submit as many cases as you like

- Enjoy fast sympathetic peer review and rapid publication of accepted articles

- Access all the published articles

- Re-use any of the published material for personal use and teaching without further permission

For information on Institutional Fellowships contact consortiasales@bmjgroup.com

Visit casereports.bmj.com for more articles like this and to become a Fellow 